\title{
POLA ASUPAN YODIUM PADA WANITA USIA SUBUR DI DESA KUSAMBA KABUPATEN KLUNGKUNG BALI 2015
}

\author{
I Kadek Ita Diatmika \\ Program Studi Pendidikan Dokter, Fakultas Kedokteran Universitas Udayana \\ diatmika27@gmail.com
}

\begin{abstract}
ABSTRAK
Yodium merupakan zat gizi yang dibutuhkan untuk pertumbuhan dan perkembangan fisik dan mental. Yodium dapat diperoleh dari berbagai jenis pangan. Berdasarkan angka kecukupan gizi, kecukupan yodium untuk wanita dewasa adalah sebesar $150 \mu \mathrm{g} / \mathrm{hari}$. Kekurangan yodium dapat menyebabkan berbagai kelainan seperti kelainan pada kecerdasan mental, pembesaran kelenjar gondok, serta gangguan pertumbuhan. Gangguan akibat kekurangan yodium pada wanita usia subur bisa mengakibatkan kelainan pada bayi yang dilahirkannya. Survei nasional pemetaan gangguan akibat kekurangan yodium diseluruh Indonesia pada tahun 1998 ditemukan 33\% kecamatan di Indonesia masuk kategori endemik. Hingga saat ini masih banyak masyarakat khususnya masyarakat pedesaan di daerah Bali belum memahami pentingnya yodium dan pemenuhan kebutuhan asupan yodium. Sehingga perlu dilakukan penelusuran bagaimana kecukupan asupan yodium khususnya pada masyarakat pedesaan. Penelitian ini bersifat deskriptif cross sectional untuk mengetahui gambaran kecukupan yodium pada wanita usia subur di Desa Kusamba berdasarkan makanan yang dikonsumsi. Populasi penelitian ini adalah wanita usia subur di Kecamatan Dawan. Pengambilan sampel dilakukan secara probability sampling dan diperoleh jumlah sampel sebanyak 90 orang responden. Data diambil dengan menggunakan kuisioner Food Frequent Quitionaire yang dimodifikasi yang kemudian dilakukan konversi dengan program komputer Nutrisurvey 2007 untuk mendapatkan asupan yodium perhari dari setiap sampel. Berdasarkan penelitian ini diperoleh rata rata asupan yodium perhari wanita usia subur di Desa Kusamba adalah 167,5 mcg, wanita usia subur dengan asupan yodium kurang sebanyak 27 orang (30\%), wanita usia subur dengan asupan yodium cukup sebanyak 63 orang (70\%). Bedasarkan pola konsumsi, kebutuhan yodium dapat terpenuhi dari pola konsumsi harian kususnya sumber yodium terbesarnya adalah ikan laut. Berdasarkan data yang didapatkan asupan yodium wanita usia subur di Desa Kusamba secara umum tergolong cukup.
\end{abstract}

Kata kunci : Kecukupan yodium, wanita usia subur, desa Kusamba

\section{IODINE INTAKE PATTERN OF WOMEN IN CHILDBEARING AGE IN THE KUSAMBA VILLAGE KLUNGKUNG REGENCY BALI 2015}

\section{ABSTRACT}

lodine is a nutrient required for the growth and development of physical and mental. lodine can be obatained from various types of food. Based on Nutrition Adequacy Score, adequacy of iodine for adult women is $150 \mathrm{mg} /$ day. Iodine deficiency can cause a variety of disorder such as mental intellect, enlargement of thyroid gland, as well as growth disorder. lodine deficiency disorder in women in childbearing age can lead to abnormalities in the baby to be born. The national survey for iodine deficiency disorder throughout Indonesia in 1998 found 33\% of district in Indonesia are endemic. Until now there are still many communities, especially rural communities in the distric of bali not understand the important of iodine and fulfillment of iodine intake. So that need to be done tracing how the adequacy of iodine intake especially in rural communities. This research is a descriptive cross-sectional study to describe the adequacy of the iodine intake of women in childbearing age in the Kusamba village based on food which they consumed. The study population 
was womens in childbearing age in Dawan District. Sampling was done by probability sampling and obtained a total sample of 90 respondents. Data were colected using modified food frequent quitionaire then be converted by a computer program which call as Nutrisurvey 2007 to get the intake of iodine per day from each sample. Based on this research, the average of iodine intake of women in childbearing age in Kusamba village was 167,5 mcg per day, women of childbearing age with insufficient iodine intake was 27 people (30\%), and women of childbearing age with sufficient iodine intake by 63 persons (70\%). Based on the iodine consumption pattern, the adequacy of iodine intake can be met from the daily consumption pattern especially from seafood. Based on the data obtained, iodine intake of women in childbearing age generally quite enough.

Keywords: lodine sufficiency, women in childbearing age, Kusamba village

\section{PENDAHULUAN}

Yodium merupakan zat gizi mikro yang dibutuhkan untuk pertumbuhan dan perkembangan fisik dan mental. ${ }^{1}$ Sekitar $75 \%$ dari yodium ada di dalam kelenjar tiroid di mana yodium ini digunakan untuk sistesis hormon tiroksin, tetraiodotironin (T4) dan Triiodotironin (T3). ${ }^{1,2}$ Hormon-hormon ini sangat penting selama perkembangan embrio dan dalam mengatur kecepatan metabolisme dan produksi kalori atau energi. $^{1}$

Yodium diekskresikan melalui saluran kencing (urin). ${ }^{3} \mathrm{Hal}$ ini dapat digunakan sebagai indikator dalam menentukan status yodium seseorang. ${ }^{3}$ Tingkat ekskresi yang rendah $(25$ $20 \mathrm{mg} \mathrm{l} / \mathrm{g}$ creatin) menunjukan status kadar yodium rendah yang umunya terakit dengan risiko kekurangan yodium. ${ }^{3,4}$

Yodium dapat diperoleh dari berbagai jenis pangan. ${ }^{2}$ Pangan asal laut seperti ikan laut merupakan sumber yodium alamiah, di mana rata - rata kandungan yodium pada ikan laut sebesar $832 \mathrm{mg}^{2}$ Sumber yodium yang lain umunya adalah garam dan air yang difortifikasi. ${ }^{2,4}$ Penggunaan garam beryodium di Amerika Serikat direkomendasikan sebagai sumber untuk memenuhi kebutuhan asupan yodium. ${ }^{3}$ Di USA konsumsi garam beryodium per hari per orang mendekati 10 - 12 gram di mana garam tersebut mengandung 76 mg yodium per gram. ${ }^{3}$

Angka kebutuhan yodium berdasarkan Angka Kecukupan Gizi 2013 untuk wanita dewasa adalah sebesar $150 \mathrm{\mu g} /$ hari. $^{5}$ Berdasarkan WHO 2001 kategori kecukupan yodium berdasarkan median population iodine nutrition dikategorikan ke dalam 3 golongan, yaitu status nutrisi yodium kurang apabila intake yodium kurang dari 149 $\mu \mathrm{g} / \mathrm{hari}$, status nutrisi yodium cukup apabila intake yodium 149 - $299 \mu \mathrm{g} / \mathrm{hari}$, dan status nutrisi yodium lebih apabila intake yodium lebih dari 299 $\mu \mathrm{g} /$ hari. $^{6}$

Kekurangan yodium dapat menyebabkan berbagai kelainan terkait dengan fungsi yodium itu sendiri. $^{3}$ Kekurangan yodium diantaranya dapat mempengaruhi kecerdasan mental, hipotiroidisme, gangguan neurologis, kretin endemic, pembesaran kelenjar gondok, serta gangguan pertumbuhan. ${ }^{2,7}$

Gangguan akibat kekurangan yodium adalah sekumpulan gejala atau kelainan yang ditimbulkan karena tubuh menderita kekurangan yodium secara terus-menerus dalam waktu lama yang berdampak pada pertumbuhan dan perkembangan. ${ }^{3}$ Gangguan ini bisa dicegah dengan mengatasi kekurangan yodium. ${ }^{8}$ Dengan mengkonsumsi pangan yang kaya yodium dapat menekan atau bahkan mengurangi besarnya prevalensi gondok. $^{8}$

Apabila gangguan akibat kekurangan yodium terjadi pada wanita usia subur bisa mengakibatkan bayi yang dilahirkan mengalami retardasi mental, mata juling, bisu, dan tuli. wanita usia subur adalah wanita yang masih berada dalam usia repodukif, yaitu antara usia 15-49 tahun. ${ }^{4,8}$ Akibat lain yang lebih mencemaskan dari wanita usia subur yang mengalami gangguan akibat kekurangan yodium adalah bayi yang dilahirkan dapat memiliki kemampuan berpikir yang lebih rendah dibandingkan dengan bayi lain yang dilahirkan oleh wanita usia subur yang tidak menderita gangguan akibat kekurangan yodium. ${ }^{8}$

Asia Tenggara merupakan penyumbang paling besar kasus gangguan akibat kekurangan yodium di dunia. ${ }^{9}$ Jumlah penderita gangguan akibat kekurangan yodium di Indonesia sendiri 
menjakup lebih dari 14 juta penduduk, yang mana diantaranya 750 orang menderita kretin, 10 juta orang menderita gondok, dan 3,5 juta orang menderita gangguan lain. ${ }^{9}$ Survei nasional pemetaan gangguan akibat kekurangan yodium diseluruh Indonesia pada tahun 1998 ditemukan $33 \%$ kecamatan di Indonesia masuk kategori endemic. ${ }^{4}$ Di mana dari 33\% tersebut diantaranya $21 \%$ digolongkan sebagai daerah endemik ringan, $5 \%$ sebagai daerah endemik sedang, dan $7 \%$ sebagai daerah endemic endemik berat. ${ }^{4}$

Hal ini menunjukan masyarakat secara umum belum sepenuhnya memahami pentingnya konsumsi yodium dan dicurigai masih banyak masyarakat yang kecukupan asupan yodiumnya kurang dan menderita gangguan akibat kekurangan yodium yang belum terdeteksi khususnya di daerah pedesaan. Hal ini didasari oleh kondisi di daerah pedesaan yang pemahaman masyarakatnya mengenai pentingnya yodium yang masih rendah. Sehingga dirasa perlu untuk dilakukannya suatu studi deskriptif untuk menggambarkan kondiisi riil masyarakat pedesaan terkait kecukupan yodiumnya.

\section{METODE}

Penelitian yang dilakukan bersifat deskriptif dengan rancangan penelitian Cross Sectional, di mana populasinya adalah wanita usia subur di Kecamatan Dawan Kabupaten Klungkung dengan populasi terjangkau wanita usia subur di Desa Kusamba. Sampel pada penelitian ini diambil secara probability sampling dari populasi terjangkau dan memenuhi kriteria inklusi dan eksklusi. Adapun kriteria inklusi yaitu wanita usia subur di Desa Kusamba, Kecamatan Dawan, sedangkan kriteria eksklusi yaitu masyarakat yang menolak ikut dalam penelitian.

Sebelumnya peneliti mengajukan permohonan penelitian kepada Kepala Desa Kusamba dan meminta data kependudukan Desa kusamba. Untuk menentukan besar sampel digunakan rumus untuk estimasi proporsi suatu populasi. Dari perhitungan berdasarkan rumus yang umum digunakan, dengan nilai $p=0,5$ dan $q=$ $1-p$ dan $d=0,1$. Sehingga didapatkan jumlah sampel yang dibutuhkan yaitu 90 orang. Peneliti memberikan penjelasan selengkap-lengkapnya tentang penelitian terhadap setiap sampel dan kemudian meminta persetujuannya untuk ikut serta dalam penelitian ini. Untuk mengetahui asupan yodium maka kuisioner digunakan uktuk menggali informasi terkait makanan yang dikonsumsi oleh wanita usia subur selama satu bulan terakhir. Kuisioner yang digunakan adalah Food Frequency Quitionaire yang dapat memberikan informasi pola konsumsi dalam jangka waktu satu bulan. Pada kuisioner ini kemudian dilakukan modifikasi untuk mendapatkan jumlah asupan setiap bahan makanan yang dokonsumsi dalam jangka waktu satu bulan yang selanjutnya dibagi kedalam jumlah asupan harian. Status asupan yodium didapat dari konversi dengan menggunakan program komputer Nutrisurvey 2007 dari jumlah rata-rata perhari dalam gram dari setiap makanan yang dikonsumsi berdasarkan data yang diperoleh dari kuisioner.

\section{HASIL PENELITIAN}

Berdasarkan hasil wawancara dengan menggunakan Food Frequency Quitionaire dari 90 sampel wanita usia subur yang memenuhi kriteria inklusi dan eksklusi didapatkan hasil bahwa dalam rentang waktu satu bulan, 90 orang sampel wanita usia subur di Desa Kusamba pernah mengkonsumsi ikan laut dengan frekuensi paling sedkitnya empat hari dalam seminggu. Ikan laut merupakan pilihan utama sebagai lauk pauk setiap harinya. dari 90 sampel tersebut didapatkan 76 orang diantaranya mengkonsumsi ikan laut sempai tiga kali dalam sehari, untuk lauk jenis lain berupa daging ayam, telur, tahu dan tempe namun tidak sesering ikan laut, untuk sayur mayur, wanita usia subur di Desa Kusamba biasa mengkonsumsi bayam, sawi hijau, kol, dan kacang panjang.

Wanita usia subur di Desa Kusamba sangat jarang bahkan tidak pernah mengkonsumsi susu dalam satu bulan terakhir, kebanyakan dari mereka lebih memilih meminum kopi dan teh. Seluruh responden hanya menggunakan garam produksi lokal yaitu garam produksi Desa kusamba sendiri sebagai bumbu masakan setiap harinya, tidak ada sampel yang menggunakan garam beryodium seperti yang dianjurkan oleh pemerintah setempat. Berdasarkan hasil survei dan perhitungan konversi pola konsumsi terhadapa intake yodium dengan NutriSurvey 2007 untuk menentukan jumlah asupan yodium perhari wanita 
usia subur di Desa Kusamba didapatkan rata - rata jumlah konsumsi yodiun perhari adalah sebesar $167,5 \mu \mathrm{g} /$ hari. Sumber asupan yodium terbesar pada wanita usia subur di Desa Kusamba berasal dari pakan ikan laut yang mampu memberikan asupan yodium rata-rata perhari untuk setiap orang sebesar 162,3 $\mu \mathrm{g}$. Sedangkan sumber asupan yodium dari bahan makanan selain ikan laut secara keseluruhan hanya mampu memberikan asupan dengan rata - rata $3,8 \mu \mathrm{g} /$ hari untuk setiap sampel. Dari 90 sampel didapatkan 27 wanita usia subur memiliki asupan yodium yang dikategorikan kurang, 63 wanita usia subur memiliki asupan yodium yang dikategorikan cukup, dan tidak didapatkanya wanita usia subur yang memiliki asupan yodium yang dikategorikan lebih berdasarkan WHO 2001 terkait kategori kecukupan yodium berdasarkan median population iodine nutrition. Sehingga prevalensi wanita usia subur di Desa Kusamba dengan asupan yodium yang tergolong kurang adalah sebesar $30 \%$, wanita usia subur di Desa Kusamba dengan asupan yodium cukup sebesar $70 \%$.

Tabel 1 Persentase Kecukupan Yodium Wanita Usia Subur di Desa Kusamba.

\begin{tabular}{lcc}
\hline $\begin{array}{c}\text { Kecukupan } \\
\text { Yodium }\end{array}$ & Frekuensi & (\%) \\
\hline Kurang & 27 & 30 \\
Cukup & 63 & 70 \\
Lebih & 0 & 0 \\
\hline Total & 90 & 100 \\
\hline
\end{tabular}

\section{DISKUSI}

Wanita usia subur di Desa Kusamba mempunyai kecenderungan untuk mengkonsumsi garam yang diproduksi sendiri oleh petani garam didaerah itu sendiri, di mana garam tersebut bukan garam beryodium seperti yang dianjurkan. Keadaan ini dikawtirkan berdampak pada rendahnya intake yodium wanita usia subur di Desa Kusamba, namun intake yodium tidak hanya dapat diperoleh dari garam beryodium, banyak sumber makanan lain yang mengandung yodiun yang apabila dikonsumsi dapat memenuhi kebutuhan yodium. Dari 90 responden yang mengikuti penelitian ini didapatkan semua wanita usia subur di Desa Kusamba mengkonsumsi ikan laut bisa sampai tiga kali sehari, hal inilah yang dapat membantu pemenuhan kebutuhan yodium per harinya, meskipun wanita usia subur tersebut tidak garam beryodium. Asupan yodium yang mampu diberikan dari pakan ikan laut rata - rata sebesar 162,3 $\mu \mathrm{g} /$ hari. Dengan melakukan konversi dari pola konsumsi wanita usia subur di Desa Kusamba terhadap asupan yodium didapatkan jumlah rata - rata intake yodium sebesar 167,5 $\mu \mathrm{g} /$ hari. Ini menunjukan pola konsumsi wanita usia subur di Desa Kusamba secara umun tergolong cukup untuk memenuhi kebutuhan yodium berdasarkan angka kecukupan gizi di mana berdasarkan angka kecukupan gizi kebutuhan yodium pada wanita dewasa adalah sebesar 150 $\mu \mathrm{g} /$ hari. Dari pola konsumsi wanita usia subur di Desa Kusamba sumber yodium terbesar berasal dari konsumsi ikan laut. wanita usia subur dengan intake yodium kurang mempunyai kecenderungan mengkonsumsi ikan laut yang kurang dibandingkan dengan wanita usia subur dengan intake yodium cukup. Berdasarkan data dari 90 wanita usia subur di Desa Kusamba didapatkan wanita usia subur dengan asupan yodium yang tergolong kurang adalah sebesar 30\%, wanita usia subur di Desa Kusamba dengan asupan yodium yang cukup sebesar $70 \%$, dan wanita usia subur di desa kusamba dengan asupan yodium yang lebih tidak ditemukan. Rendahnya penggunaan garam beryodium di Desa Kusamba tidak diikuti dengan tingginya wanita usia subur dengan kecukupan asupan yodium yang kurang, wanita usia subur dengan asupan yodium kurang hanya sebesar $30 \%$. Bedasarkan pola konsumsi wanita usia subur di Desa Kusamba kebutuhan yodium dapat terpenuhi dari pola konsumsi harian kususnya sumber yodium terbesarnya adalah ikan laut. Dengan proporsi wanita usia subur dengan asupan yodium rendah hanya $30 \%$ menunjukan wilayah ini belum bisa dikategorikan sebagai daerah dengan masyarakat yang asupan yodiumnya tergolong rendah.

\section{SIMPULAN}

Tujuan dari penelitian ini adalah untuk mengetahui status kecukupan yodium pada wanita usia subur di Desa Kusamba, Kecamatan Dawan, Kabupaten Klungkung. Berdasarkan hasil penelitian dan uraian dari pembahasan dapat ditarik kesimpulan yaitu : 
1. Sumber yodium utama yang mampu memenuhi kebutuhan asupan yodium wanita usia subur di Desa kusamba bersal dari pakan laut yaitu ikan laut yang mampu memberikan asupan yodium rata-rata sebesar 162,3 $\mu \mathrm{g} /$ hari yang tidak bisa didapat dari garam beryodium.

2. Jumlah rata - rata konsumsi yodium wanita usia subur di Desa Kusamba perhari adalah sebesar 167,5 mcg, di mana ini menunjukan secara umum asupan yodium wanita usia subur di Desa Kusamba tegolong cukup.

3. Wanita usia subur di Desa Kusamba dengan asupan yodium yang tergolong kurang adalah sebesar 30\%, dan 70\% memiliki asupan yodium yang tergolong cukup. Sedangkan wanita usia subur dengan asupan yodium yang tergolong lebih tidak ditemukan

\section{DAFTAR PUSTAKA}

1. Picauly, Intje. Iodium dan Gangguan Akibat Kekurangan lodium. Program Pasca Sarjana IPB. Bogor. 2002.

2. Gatie, Aih Luh. Validasi Total Goitre Rate (TGR) Berdasar Palpasi terhadap Ultrasonografi (USG) Tiroid serta Kandungan Yodium Garam dan Air di Kecamatan Sirampog Kabupaten Brebes. Thesis Universitas Diponegoro. 2006.

3. Thesa. GAKI (Gangguan Akibat Kekurangan lodium). 2009.

4. DepKes RI. Gangguan Akibat Kekurangan lodium dan Garam Beriodium. Pusat Penyuluhan Kesehatan Masyarakat. 2003.

5. Hartono, Bambang. Gangguan Perkembangan Otak Janin Akibat Defisiensi Yodium pada Masa Kehamilan. 2005.

6. World Health Organization. Assessment of IDD and Monitoring Their Elimination. $2^{\text {nd }}$ edition. 2001.

7. Ritanto, Mus Joko. Faktor Risiko Kekurangan Yodium pada Anak Sekolah Dasar di Kecamatan Selo Kabupaten Boyolali. Thesis Universitas Diponegoro. 2003.

8. Santosos Eko Budi, Hamam Hadi, Toto Sudargo. Hubungan antara Konsumsi Makanan Goitrogenik dan Status lodium pada Ibu Hamil di Kecamatan Endemis Gangguan Akibat Kekurangan lodium. Berita Kedokteran Masyarakat. 2006. Vol.22, No.3.

9. Arisman. Gizi dalam Daur Kehidupan. Jakarta : EGC ;p.132-4. 2004. 